\title{
Japan: What to Do with Dead Bodies? A Burning Issue
}

\author{
Andy Crump \\ Kitasato University, Shirokane, Minato-ku, Tokyo, Japan
}

\section{Corresponding author:}

\section{Andy Crump, PhD}

Kitasato University, 5-9-1 Shirokane, Minato-ku, Tokyo 108-8641, Japan

Email:acys@me.com

Submitted : Mar 20, 2020

Accepted : Apr 2, 2020

\begin{abstract}
Death, the passing of a loved one, friend, colleague or just someone we may have known, is virtually always sad and often traumatic. However, it is a part of life and has to be coped with. Each year around 60 million people worldwide die from a wide and diverse number of causes. The problem of what to do with all those dead bodies is becoming a major conundrum for the families involved as well as for policy makers and governments. Natural and anthropogenic disasters, together with increasing incidence of major pandemics of infectious diseases is making finding a solution ever more difficult. A problem which is made worse by ever-increasing draconian rules about what can and cannot be done when disposing of a body.

Currently, there are two basic choices, either bury the body in the ground where such action is permitted or cremate it and dispose of the ashes in a culturally and legally acceptable fashion. Generally, both options are becoming prohibitively expensive. The cost of land and the burgeoning demand for land to be used for industry, agriculture, urbanised centres or leisure activities is making burial no longer an option for most people. Japan has long led the world in incineration technology and it has also led the world for many years in cremating its dead. Virtually all Japanese are now cremated, the funeral process involving a mixture of high technology and unique routines steeped in history. Despite widespread concerns that cremation can cause environmental pollution and may damage public health as a result, it is still deemed less polluting than burial. It is likely that countries around the globe will increasingly adopt a policy of cremating their deceased citizens and would do well to follow the lead in this respect being shown by Japan.
\end{abstract}

Keywords: Cremation, dead bodies, incineration, Japan

\section{INTRODUCTION}

$\mathrm{M}$ uch attention has been focussed recently on the social, environmental and economic determinants of health. However, little heed has been paid to the environmental and socioeconomic aspects of death. In Japan, the world's healthiest country, where the citizens enjoy the world's longest life span, over 1.3 million people die each year. This means that the nation has to cope with an average of over 3,500 dead bodies every day. The death toll has been steadily increasing for over 30 years and is forecast to rise to 1.68 million by $2039 .{ }^{1}$ Anyone who has spent time or lived in Japan will know that the problem is dealt with in a relative efficiently and somewhat unique way - especially those of us who have had to undergo the trauma of a Japanese funeral. And, as is inescapable in Japan, the old ways are clashing with the new.

Cremation in Japan originates in Buddhism, the practice arising from the belief that the Buddha's dead body was burned and his soul transmigrated. 


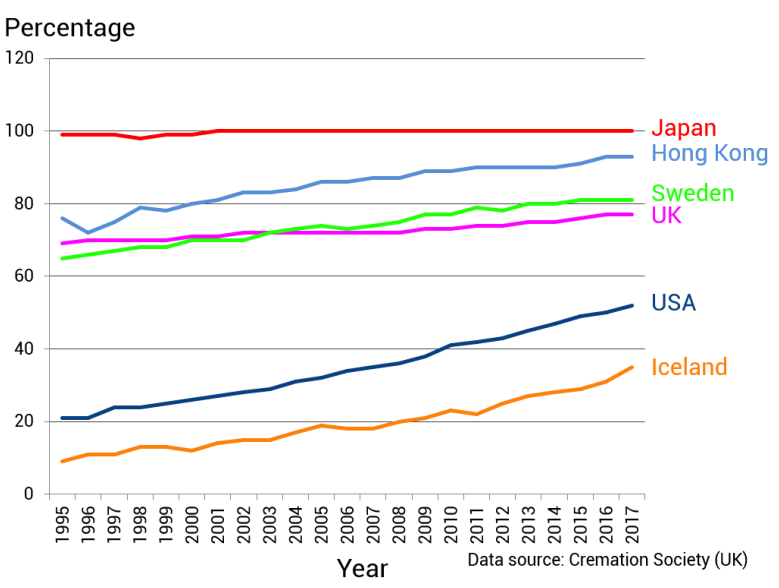

Fig 1. Trends in cremation (\% of cadavers cremated)

The first cremation in Japan was reported along with the introduction of Buddhism in the $6^{\text {th }}$ century. Originally, only monks and high-social strata people were cremated because wood used for the fires was expensive and meant defiling Nature in the process.

In India, the problems of cremation are well known, and getting worse, but reflect what happened historically in Japan. The Ganges River, running through India and Bangladesh, is a sacred place for the mainly Hindhu people who live along its banks. Hindus believe that the river is a purification tool and that submerging the ashes of the deceased in its waters will grant them eternal salvation. Along the river there are crematoria that function 24 hours a day, seven days a week, continuously, with 30100 bodies handled daily, each taking about three hours to burn. Hindus want their ashes cast into the river immediately after cremation, believing that this will break the perpetual cycle of samsara, or reincarnation, and thus achieve Moksha. ${ }^{2}$ Families have always been pressurised to purchase the best kind of wood for the cremation but the historical practice has meant that all wood is now both extremely scarce as well as expensive. Sandalwood burns best and cleanest but fetches the highest price. A cremation can cost over 7,000 Indian rupees (US\$109), which represents over $15 \%$ of the average annual wage. For centuries, the crematoria have been plying a trade that is both expensive and environmentally damaging, due to the air pollution from the funeral pyres and pollution of the river by the ashes. It is now prohibitively expensive for most families to afford a cremation and so many have taken to just casting dead un-cremated cadavers of relatives into the river. The outcome is that the Ganges is viewed as one of the most polluted rivers in the world. ${ }^{3}$ Dead bodies and ashes exacerbate the already high levels of pollution, with an estimated 35,000 bodies being discarded into the river annually. Despite a continuous outcry to

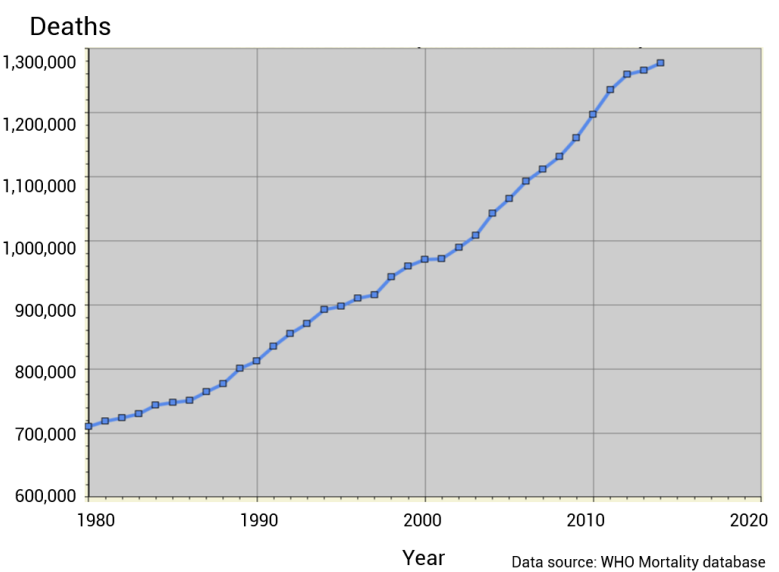

Fig 2. Deaths in Japan

(all cause; 3-point sliding mean)

clean the river up, the Indian authorities have made little progress in doing so.

In Japan, before and during World War II, burials were the norm, cremation spreading nationwide only after the war due to a combination of land in urban areas being limited, for sanitary reasons, and to preserve the nation's ubiquitous and treasured forests. Cremation is beneficial in that it generally gets rid of many viruses, germs and bacteria through searing heat and evaporation, although the process itself can be polluting. In Japan now, it is said that only the Japanese Imperial family are not cremated, the 2017 cremation rate being 99.97\%, the highest in the world, with an upward cremation trend being shown globally (Fig. 1). In Japan, cremation has become increasingly commonplace, especially in urban areas, due to limited space for burials, government policies and traditional and religious factors. All this has been happening during a time when the actual number of Japanese dying was steadily rising (Fig. 2). During this period, Japan also became a world leader in incineration technology, with over $80 \%$ of household waste being safely and efficiently disposed of through the nation's advanced-technology, pollution-free waste incineration facilities. Crematoria similarly became more efficient with a move to electricity from the more environmentally damaging coal and oil. Electricity had been used for the first time in a Kyoto crematorium in 1922, reducing cremation time to about one hour. ${ }^{4}$ Nowadays temperatures and type of combustion can be customised to produce the type of ashes desired by the family, with urban crematoria using gas whereas some of those in rural areas still use kerosene (paraffin).

In scientific terms, cremation is the combustion, vaporization, and oxidation of cadavers to their basic chemical compounds, such as gases, ashes and mineral fragments. As the human body comprises $75 \%$ liquid and $25 \%$ solids (flesh and bones), the liquid part evaporates and is released as gas, while 
the solid components become dust and ash. ${ }^{5}$ In religious terms, Japan's beliefs about the body and the spiritual world have a significant impact on the cremation process itself. In economic terms, the cost of land in Japan makes anything other than cremation prohibitively expensive, and increasingly so. The average cost of a funeral in Japan is currently around $¥ 2$ million (about $\$ 20,000$ ), the highest in the world, three times higher than the United States and 10 times higher than in Britain.

\section{THE WESTERN APPROACH}

In the Western world, cremation occurs in a cremator, an industrial furnace that can generate temperatures of $760-1150^{\circ} \mathrm{C}\left(1400\right.$ to $2100^{\circ} \mathrm{F}$ ) to guarantee disintegration of the corpse. Some European and North American nations do employ the practice but nowhere near as committedly as in Asia (Table 1). Ordinarily, metal jewellery is removed before cremation and returned to the family. Several implanted devices, such as pacemakers, must also be removed. The casket containing the body is placed in the retort (furnace) and incinerated. During the cremation process the heat dries, burns and eventually vaporises the soft tissues and calcifies bones so they crumble. There is usually no smell because the emissions are processed to destroy smoke and vaporize gases, which are discharged through an exhaust system. Some crematories even have a secondary afterburner to help ensure the body is burnt completely. The process usually takes 90 minutes or so, with larger bodies taking more time. When cremation is finished, the remains are passed through a magnetic field to remove any metal, which will be disposed of or, increasingly, recycled. Contrary to popular belief, the cremated remains are not ashes in the true sense. After the incineration is completed, dry bone fragments are swept out of the retort and pulverised by a machine called a cremulator which processes them in seconds into "ashes" or "cremated remains" known as "cremains." If there is no machine available, this task is done by hand by a crematorium technician. The outcome is a final mixture of crushed bone and ash with a fine sand-like texture and colour, able to be easily scattered. The mean weight of ashes of an adult is around $2.4 \mathrm{~kg}$.

\section{THE ORIENTAL APPROACH}

The Japanese have a surprisingly flexibility when it comes to religion, usually opting for a Shinto birth, a Christian wedding and a Buddhist funeral. So, after a Japanese person dies he or she is usually honoured in the Buddhist tradition. Cremation is considered a crucial purification rite before entering the next life. Some elderly people interviewed after the Great East Japan Earthquake and tsunami in 2011 said they faced a life of utter despair if they couldn't find the bodies of their relatives to honour properly, while others believed the spirits of their loved ones would haunt them unless they got a proper funeral. In Japan, kerosene is widely used as a fuel in industry as well as in households and in older rural crematoria. Cremation requires around 38 litres of kerosene and, after the 2011 disaster, it was in short supply in the affected regions, causing some local governments to start burying the dead, which caused yet more consternation and anguish for an already traumatised community.

In the Japanese cremation process, the clash between the old and the new is quite evident. It is ironic that most Japanese funeral services are Buddhist because Buddhism in its original form did not place much importance on such matters. In fact, Buddhism did not play a big part in funeral services until the Edo Period (1603-1867) when the shogun forced all people to register as Buddhists as part of an effort to eliminate Christianity. After World War II when Buddhist monks were stripped of their land holdings, they actually turned to funerals as their primary source of income.

In modern-day Japan, according to Buddhist customs, a dead person, usually on a bed of dry ice, is returned to their home as soon as possible, family members staying with the body of the deceased until the funeral takes place so that friends and relatives may visit the departed one and pay their respects. On the day of the funeral, the deceased is placed in a wooden coffin which is wrapped in fine cloth. The departed are dressed in a white kimono and surrounded by some of their favourite earthly possessions plus they carry six coins for safe passage across the "Sanzu-no-kawa" (Sanzu River or River of Three Crossings). This is a river located in northern Japan which the dead are believed to pass on the seventh day after death on the way to the afterlife. The coffin lies open in the funeral ceremony room and mourners may place additional flowers and other small memorabilia or items of all kinds into it. After the religious rituals have been completed and people have put whatever they felt relevant into the coffin along with the deceased, the casket is closed and moved to a furnace room and placed on a movable tray in front of the cremation chamber. The lead mourner, usually a spouse or the eldest son, ceremonially presses a button to start the process. It takes around 1.5-2 hours to cremate an adult body in Japan because it is done in a different way, at a lower heat, to achieve a different end result. Upon completion, the tray exits the furnace with the entire skeleton visible, lying in a pile of ash from the burning of the body's soft tissues and everything combustible that was placed in the coffin. This sight, in scorching heat, is solemnly viewed by the lead mourner, who then re-joins the immediate family in another room where the bones of the deceased skeleton are brought in on trays. 
The bones are ceremoniously picked up using long chopsticks, often one bamboo and one willow to signify the physical and the spiritual worlds, and forced into a ceramic urn. Two mourners, each wielding one chopstick, can together pick up a bone to manipulate it into the urn and this is the only time in Japan when it is proper manners and acceptable for individuals to use chopsticks to hold or pass the same item at the same time. The Japanese revere the bones much more than ashes. Indeed, the actual ashes may be completely discarded by the funeral home staff at this point. The bones often have to be broken to fit into the urn. Ideally, they will be placed in the urn starting from the feet so that the person is not upside down in their final resting place. Added last, the skull is usually unceremoniously crushed to ensure that it will fit into the urn. The small hyoid bone is the most sacred and significant. Located in the neck, meaning it links brain and body, it looks like the image of a seated Buddha, and is the last to be put into the urn. The urn is then closed and handed to the chief mourner.

Cremains are returned to the next of kin in different manners according to custom and country. The Western process is not what transpires in Japan because of the nation's propensity to venerate the bones of their ancestors. In East Asian countries such as Japan the bones are not pulverised, unless requested beforehand. This allows the hallowed "Bone Picking' ceremony to take place. It is the bones that are collected by the family and kept at home, or interred in the family grave or stored as one might do with ashes. This is why many Japanese make sojourns to Pacific islands and other parts of Asia where wars have been fought so that relatives may try to recover the bones of their ancestors who died during the fighting.

\section{ENVIRONMENTAL IMPACT OF CREMATION}

Not surprisingly, the focus on cremation has meant that Japan is now home to 1,460 crematoria, and cremations are big business. However, crematoria can have a significant detrimental impact on the local environment. Generally speaking, each cremation uses about $100 \mathrm{~L}$ of fuel and electricity, releasing about $240 \mathrm{~kg}$ of carbon dioxide into the atmosphere. It has been estimated that the 1 million bodies cremated annually in the USA produces about 240,000 tonnes of carbon dioxide, more $\mathrm{CO}_{2}$ pollution than 22,000 average American homes generate in a year. In comparison, Japan cremates 33\% more bodies, although they are mostly considerably less sizable. The burners can range in power from $150 \mathrm{~kW}$ to $800 \mathrm{~kW}$ with most modern furnaces now running on gas. A $68 \mathrm{~kg}$ body which contains $65 \%$ water will need $100 \mathrm{MJ}$ of thermal energy before any combustion will take place. This is equivalent to $3 \mathrm{~m}^{3}$ of natural gas or $3 \mathrm{~L}$ of fuel oil. Additional energy is necessary to preheat the furnace if it is not already up to temperature. Furnaces are commonly lined with ceramic bricks which, themselves, require a lot of energy to produce.

Calcified compounds within cremains can contain metals such as lead, boron, cadmium, chromium, cobalt, copper, tin, lithium, magnesium, manganese, nickel and strontium. Metals such as arsenic and selenium, though present in a live human body, are volatile and decompose quickly upon burning. Exhaust gases are usually vented through a refractory-lined flue but even though the gases are cooled before release, they remain the greatest source of cremation pollution. Emissions include carbon dioxide, carbon monoxide, nitrogen oxide, sulphur dioxide, hydrogen chloride, hydrogen fluoride and mercury vapour. Organic compounds such as benzenes, furans and acetone are also emitted and these can react with the hydrogen chloride and hydrogen fluoride to form polychlorinated dibenzodioxins (PCDDs) and polychlorinated dibenzofurans (PCDFs), both known carcinogens $\mathrm{s}^{7-10}$ and these are becoming a significant problem due to their toxicity and adverse health implications. Despite this, studies on the dangers of emissions from crematoria are scarce, with virtually none on the impact of nitrogen dioxide $\left(\mathrm{NO}_{2}\right)$, carbon monoxide $(\mathrm{CO})$, sulphur dioxide $\left(\mathrm{SO}_{2}\right)$ or polycyclic aromatic hydrocarbons (PAHs). ${ }^{11,12}$

In the UK a cremator uses about $285 \mathrm{kWh}$ of gas and $15 \mathrm{kWh}$ of electricity on average per cremation - around the same domestic energy used by a single person for an entire month. Aside from the considerable amount of greenhouse gas emissions this creates, the UK's Environment Agency confirms that cremation is also responsible for $16 \%$ of the UK's mercury pollution (due to the dental fillings in cremated bodies). The industry's crematoria were instructed that they all had to halve mercury emissions by 2012, but, ironically, the best way to accomplish this is to cremate at a higher temperature, thereby leading to more gaseous emissions. Globally, very limited data on mercury emissions from crematories have been published. According to the UK's Department for Environment, Food and Rural Affairs (DEFRA), mercury emissions in 2020 will be 1.67 times those in 1995 and will peak in $2035 .{ }^{13}$ This will contribute $11-35 \%$ of the total mercury emissions in the United Kingdom in 2020. In Sweden, crematories were estimated to be the third highest contributor of all anthropogenic sources of mercury. ${ }^{14}$ Emissions from crematories are also very likely to have a significant impact in Japan. The annual amount of mercury emission from Japanese crematories has been estimated to be considerably lower than that in the UK, although it is also projected to increase 2.6-fold between 2007-2037. ${ }^{15}$ 
As is frequently the case, China faces the continuing problem of scale and need. The traditional practice in China has been to bury the dead, with some 3.3 million ha out of the country's 80 million ha of arable land rendered infertile by ancestral graves. During the early-1990s, an estimated 75,000 ha of land was lost annually for burial plots and 3 million $\mathrm{m}^{3}$ of wood, the total annual production of Fujian province, was used for coffins. However vast and unobtainable amounts of land, often that which is essential and best suited for farming, would be needed to cope with the country's 9-10 million annual deaths. Consequently, over the past few decades, the Chinese government has been actively promoting cremations, as well as encouraging burials at sea. The Yishin Crematory, the world's largest, is located in Shanghai, its 24 incinerators helping to cope with the 100,000 people that die in Shanghai each year. But by 2014 , only $45.6 \%$ of China's 9.6 million dead were disposed of through cremation, well below the government's intended target.

\section{CREMATION: 'BIG BUSINESS' OR A SOCIAL SERVICE}

In Japan, death will remain an increasingly major and probably profitable business for the immediate and mid-term future and there are 8,550 domestic firms selling funeral services. In 2017, the government reported that there were 4,181 crematoria - of which only 1,432 had been actually operating during the year - carrying out 1,400,282 cremations. ${ }^{16}$ The funeral market value was forecast to be around $¥ 1.84$ trillion (US\$1.67 trillion ) in 2018, up from $¥ 1.76$ trillion (US\$1.62 trillion) in 2014. ${ }^{17}$ However, most crematoria are operated by local governments, so tend to lose money, since cremation is considered a public health and social service. Tokyo's 23 wards house nine crematoria, six of which are private. One of the biggest, in the Itabashi ward, cremates 14,000 bodies a year. It has 15 furnaces that are ranked according to speed of incineration. In Tokyo almost all crematoria are booked solidly a long time in advance, although there are occasionally openings in the early morning. This situation has given rise to a new business of 'Corpse Hotels', which keep dead bodies on ice until the cremation can take place. One such hotel in Kawasaki, a large city nearTokyo with an acute shortage of crematoria, charges $¥ 9,000$ (US\$80) per night and bookings are reportedly at $75 \%$, higher than for regular hotels in the city. Yokohama, Japan's second most populous city, only has five crematoria - four public and one private. The newest, built in 1991, in anticipation of increased demand, has 10 furnaces and carries out a maximum of 20 cremations a day, apart from in winter when the number of deaths typically increases, when they undertake 26 daily. ${ }^{18}$ As a sign of the times, Japanese society is ageing rapidly and not all friends and relatives can queue to pay tribute to the deceased. The funeral home Ueda-Minami Aishoden in Nagano introduced Japan's first drivethrough funeral option, designed for the elderly and infirm. Visitors register at a drive-through window, pass condolence money to the staff and burn some incense. Respects and farewells can be made electronically via video links to the family without having to leave the car.

\section{WHAT TO DO WITH THE REMAINS?}

Meanwhile, in Japan, the shortage of space and the high cost of land and funerals has led many Japanese to consider alternatives for what to do with their cremains. More and more people are scattering the ashes of deceased relatives on Mount Fuji or in the sea, a practice considered unacceptable until the early 1990s. Typically for Japan, new technology is being brought to bear and novel 'cybergraves' are also becoming more common. ${ }^{19}$ A 30-year membership to the Cyberstone Service by Kudokuin Temple in Tokyo, which features video and pictures of a deceased loved one that can be accessed with a cell phone or computer, costs a mere $¥ 170,000$ (\$1,500). A new phenomenon of "Grave Apartments' is also emerging. In some, a small locker in a large bank of lockers can be purchased to store the cremains, some including a touchscreen allowing the showing of photos of the deceased, a family tree or even messages. Others comprise a sealed box kept in an underground vault. If you want to access the box, you scan a key card and your box is delivered to a quiet area for prayer. Tokyo Gobyo, a 5-storey facility, can store the remains of around 7,000 people. There is also some discussion about offering "Rent-tombs", where a deceased person would be allowed to occupy a grave for certain amount of time, after which the ashes would be moved or scattered, and the grave would be occupied by someone else.

What to do with human remains will continue to be a significant problem for the foreseeable future, as is becoming apparent in Japan. Reports have been increasingly emerging of a growing mountain of unclaimed cremains in urns piling up all over the country. This is due to the breakdown of family ties and the high cost of funerals, emphasising the social, economic and demographic upheavals prevailing in Japanese society. So many people are dying that relatives now either refuse to collect urns from funeral homes, or the authorities cannot identify or locate the relatives in the first place. Family members may hardly know the deceased, especially as there are now so many 1-person households of extremely elderly people, plus the onerous traditional responsibility of the eldest son in the family taking care of their parents and other family is increasingly being rejected. In Yokosuka, authorities have taken to combining the ashes of different people in larger receptacles and storing 
them in caves. In Saitama, the number of unclaimed urns has exceeded 1,700 while in Fukuoka, the total is over 6,000. In Osaka, over 2,000 remains that had been unclaimed after two years were actually buried in a communal grave..$^{20}$

As Japan's example demonstrates, the use of crematories seems to be a viable and comparatively harmless option with respect to the environment, due to the simple fact that the process causes much lower negative impact than burial. Ecologically sound alternatives to both burial and cremation are still being sought, including a proposal in Sweden to use liquid nitrogen to freeze-dry the deceased into brittle, compostable remains, while several dozen Japanese have already had their ashes launched into space in "space burials" provided at high cost by mostly US-based companies.

\section{CONFLICT OF INTEREST}

The author declares no conflicts of interest.

\section{FUNDING}

No funding whatsoever was received for the research and production of this article.

\section{REFERENCES}

1. Ministry of Health, Labour and Welfare (MHLW), Vital Statistics, online available at https://www. mhlw.go.jp/english/wp/wp-hw11/dl/01e.pdf

2. Conaway, C. The Ganges River Is Dying Under the Weight of Modern India. Newsweek. 20 Apr. 2016. Web. 04 Apr. 2017. <http://www.newsweek. com/2015/10/02/ganges-river-dying-underweight-modern-india-375347.html>.

3. Shar $T$, Ray $C$ \& Lele, U. How to clean up the Ganges? Science 2018:362 (6414); 503

4. Picone M. Cremation in Japan : bone Buddhas and surrogate bodies, Études sur la mort, 2007/2 (n०132), p. 131-140. URL : https://www.cairn.info/ revue-etudes-sur-la-mort-2007-2-page-131.htm

5. Costa AC. Barros CEC and Pinto PA. Implementation of a Crematorium in Maceio: A Study of the Market Potential (in Portuguese), XXVII National Meeting of Production Engineering - ENEGEP, Foz do Iguaçu, Paraná, Brazil, 2007.

6. Green J, Green M. Dealing With Death: Practices and Procedures. Jessica Kingsley Publishers. p. 112. 2006. ISBN 1-84310-381-8.

7. Smith TO, Gitsham $P$, Donell ST et al. The Potential Dangers of Medical Devices with Current Cremation Practices, European Geriatric Medicine. 2012:3(2);97-102.
8. Takeda N, Takaoka M, Oshita K et al. PCDD/DF and Co-planar PCB emissions from crematories in Japan. Chemosphere, 2014: 98; 91-98.

9. Cheruiyot,NK, Lee WJ, Yan $P$ et al. An overview of PCDD/F Inventories and Emission Factors from Stationary and Mobile Sources: What we know and what is missing. Aerosol and Air Quality Research 2016: 16 (12); 2965-2988.

10. Xue, Y., Tian, H., Yan, J., Xiong, C., Pan, T., Nie, L. and Zhu, C. Present and future emissions of HAPs from crematories in China. Atmospheric Environment, 2016: 124 (Part A); 28-36.

11. Mari, Montse \& Domingo, Jose. Toxic Emissions from Crematories: a review. Environment International. 2009: 36; 131-137.

12. Cruz NJT, Lezana AGR, Santos PCF et al. Environmental impacts caused by cemeteries and crematories, new funeral technologies and preferences of the Northeastern and Southern Brazilian population as for the funeral process. Environmental Science and Pollution Research International. 2017:24 (31); 1-14.

13. Department for Environment Food and Rural Affairs (DEFRA), UK. Mercury emissions from crematoria - Second consultation, Department for Environment, Food and Rural Affairs; Welsh Assembly Government; Scottish Executive Environment and Rural Affairs Dept. 2004 Available at: http://www.defra.gov.uk/corporate/ consult/crematoria-two/consultation.pdf, 2004.

14. Hogland, W. Usefulness of selenium for the reduction of mercury emissions from crematoria. J. Environ. Qual. 1994: 23; 1364-1366.

15. Takaoka M, Oshita K, Takeda N, Morisawa S. Mercury emission from crematories in Japan Atmos. Chem. Phys. 2010: 10; 3665-3671. www. atmos-chem-phys.net/10/3665/2010/

16. Ministry of Health, Labour and Welfare (MHLW) Japan. Public Health Administration Report. 2019 Available from http: //www.e-stat.go.jp/SG1/estat/ List.do?lid=000001035603, 2008a.

17. Engelman J. Sales value of the funeral business market in Japan from 2014-2018. Statista. 2018. Available from: https://www.statista.com/ statistics/794383/japan-funeral-businessmarket-size/

18. Brasor $P$ \& Tsubuku $M$. Where to burn aging Japan's growing numbers of dead? Japan Times. November 26, 2016

19. McNeil D. The Business of death: profiting from loss in Japan. Irish Times. August 31st. 2017.

20. Kaneko K. Unclaimed burial urns pile up in Japan amid fraying social ties. Reuters World News. October 19, 2018 (Available at: https://www. reuters.com/article/us-japan-ageing-urns/agingjapan-unclaimed-burial-urns-pile-up-in-japanamid-fraying-social-ties-idUSKCN1MTORH) 